\title{
DISPARATE IMPACT, DISPARATE TREATMENT, AND THE DISPLACED HOMEMAKER
}

\author{
MARILYN V. YARBROUGH*
}

I

\section{INTRODUCTION}

All marriages end. When a marriage ends because of death, the surviving spouse typically is a woman. Also typically, provisions for her continued support are inadequate. When a marriage ends in divorce, the female partner usually must find some way of supporting herself. Even when the marriage does not end, disability of a husband or inflation and familial needs sometimes make it imperative that a wife return to work. In all these cases, older women without recent experience in the labor force traditionally have found it difficult to qualify for any except the most menial jobs. ${ }^{1}$ A federal district court recently decreed that use of a "recency factor" in evaluating a woman's qualifications for a position has a discriminatory impact on older women possibly constituting gender and age discrimination in the absence of other defenses to such claims. ${ }^{2}$

Four circuit courts of appeals ${ }^{3}$ have considered the standard of proof to be used, and all $^{4}$ have accepted proof of disparate impact as prima facie evidence of discrimination in cases involving the Age Discrimination in Employment Act of 1967 (ADEA). ${ }^{5}$ The United States Supreme Court, with Justice Rehnquist dissenting, denied certiorari in the only such case to reach it to date. ${ }^{6}$ Justice Rehnquist's dissent stated that the Supreme Court had never found disparate impact to be the proper standard in age discrimination actions brought under the ADEA. ${ }^{7}$ Although Rehnquist's view enjoys support

Copyright (C) 1986 by Law and Contemporary Problems

* Professor of Law and Associate Vice Chancellor, University of Kansas. I am indebted to Molly Daniels and Martin Wisneski for their invaluable research assistance.

1. See generally The Role of Older Women in the Work Force: Hearings Before the Joint Economic Comm., 98th Cong., 2d Sess. 1-67 (1984).

2. Haskins v. Secretary of HHS, 35 Fair Empl. Prac. Cas. (BNA) 256 (W.D. Mo. 1984).

3. Leftwich v. Harris-Stowe State College, 702 F.2d 686 (8th Cir. 1983); Allison v. Western Union Tel. Co., 680 F.2d 1318 (11 th Cir. 1982); Douglas v. Anderson, 656 F.2d 528 (9th Cir. 1981); Geller v. Markham, 635 F.2d 1027 (2d Cir. 1980), cert. denied, 451 U.S. 945 (1981). The Sixth Circuit claims to use a case-by-case approach. See Blackwell v. Sun Elec. Corp., 696 F.2d 1176, 1187 (6th Cir. 1983).

4. Leftwich, 702 F.2d at 690; Allison, 680 F.2d at 1321; Douglas, 656 F.2d at 531-32; Geller, 635 F.2d at 1032 .

5. 29 U.S.C. $\$ \$ 621-634$ (1982).

6. Markham v. Geller, 451 U.S. 945 (1981).

7. Id. (Rehnquist, J., dissenting). 
from some federal district courts ${ }^{8}$ and commentators, ${ }^{9}$ appellate courts that have analogized the ADEA to Title VII of the Civil Rights Act of 1964 have concluded that it is possible to maintain both disparate impact and disparate treatment cases. ${ }^{10}$ The leading treatise on employment discrimination supports the appellate court. ${ }^{11}$

Courts have found disparate impact when practices that are neutral with regard to potentially discriminated classifications (for example, race, age, gender) nevertheless operate to discriminate against members of the protected classifications. ${ }^{12}$ In disparate treatment employment discrimination cases, an employer intends to and does treat members of a protected classification less favorably than others because of such factors as race, age, and gender. ${ }^{13}$ Proponents of the disparate-treatment-only doctrine sometimes employ reasoning suggesting that, because Griggs v. Duke Power Co., ${ }^{14}$ the Title VII case initially describing the disparate impact doctrine, depended on evidence of existing disadvantage caused by prior discrimination, ADEA cases with no such historical "baggage" are not analogous. ${ }^{15}$

This article examines the two doctrines, disparate impact and disparate treatment, as they relate to the Age Discrimination in Employment Act, and tests the theories most commonly set forth in such analyses in the context of displaced homemakers-a group which only recently has been recognized as a victim of age discrimination in employment.

The problem of the displaced homemaker above the age of 40 is the same problem faced by all older workers. The displaced homemaker often is discriminated against in hiring for a number of age-related reasons. She is considered too old for training programs. Her benefits will more often than not cost the employer more than benefits for a younger worker. The number of years she might serve the employer is limited. Traits such as inflexibility, lack of stamina, and health problems that could affect any older worker routinely are attributed to her regardless of her individual circumstances. The burden of having employers discount skills and experience without allowing them to be demonstrated and documented affects displaced homemakers disproportionately. The acceptance of such discounting by the law and society makes it easy to defend an age discrimination action by citing "reasonable factors other than age." Unfortunately, none of the existing

8. E.g., Williams v. City \& County of San Francisco, 483 F. Supp. 335 (N.D. Cal. 1979); Mastie v. Great Lakes Steel Corp., 424 F. Supp. 1299 (E.D. Mich. 1976).

9. Player, Proof of Disparate Treatment Under the Age Discrimination in Employment Act: Variations on a Title VII Theme, 17 GA. L. REv. 621 (1983); Note, Age Discrimination and the Disparate Impact Doctrine, 34 StAN. L. ReV. 837 (1982).

10. See, e.g., Douglas v. Anderson, 656 F.2d 528 (9th Cir. 1981); Geller v. Markham, 635 F.2d 1027 (2d Cir. 1980).

11. 3 A. Larson \& L. Larson, Employment Discrimination $\$ 102.42$ (1984).

12. See, e.g., Griggs v. Duke Power Co., 401 U.S. 424, 431 (1971).

13. See, e.g., International Bhd. of Teamsters v. United States, 431 U.S. 324, 335 n.15 (1977).

14. 401 U.S. 424 (1971).

15. See, e.g., Williams, 483 F. Supp. at 344. 
legislation prohibiting discrimination on the basis of age or gender has been used successfully to attack the problem of the displaced homemaker.

\section{ADEA}

The ADEA prohibits employment discrimination based on age. ${ }^{16}$ When Congress first considered discrimination in the hiring phase of employment, its concern was for the person who traditionally had been the family's breadwinner, found himself without a job, and was experiencing difficulty in finding one because of his age. The effect of unemployment on the breadwinner and his family is the subject of much of the history of the ADEA. ${ }^{17}$

Attempts to include age as a protected classification in Title VII and subsequent attempts to amend Title VII to include age proved unsuccessful. ${ }^{18}$ Pre-ADEA legislation ${ }^{19}$ and executive $\operatorname{acts}^{20}$ also were largely inadequate to combat age discrimination. A report from the Secretary of Labor, mandated by the Civil Rights Act of 1964, served as the basis for separate passage of the ADEA. ${ }^{21}$ The purpose of the ADEA legislation was stated in both the House and Senate Reports recommending its passage:

To promote the employment of older workers based on their ability. This would be done through an education and information program to assist employers and employees in meeting employment problems which are real and dispelling those which are illusory, and through the utilization of informal and formal remedial procedures. 22

Background material for the House and Senate Reports cited the Secretary of Labor's rejection of new nonstatutory methods for dealing with age discrimination ${ }^{23}$ and President Johnson's message to Congress ${ }^{24}$ recommending the ADEA and directing the Secretary of Labor to establish a comprehensive program of information, counseling, and placement services for older workers.

16. 29 U.S.C. $\$ \S 621-34$ (1985).

17. See generally President's Special Message to Congress Proposing Programs for Older Americans, 1967-I PUB. PAPers 32 (refers principally to those who have been employed and are no longer able to retain or regain employment because of age discrimination) [hereinafter Special Message].

18. H.R. 16972, 93d Cong., 2d Sess. (1974); H.R. 17383, 93d Cong., 2d Sess. (1974); see also Age Discrimination in Employment: Hearings on Age Discrimination Bills Before the Subcomm. on Labor of the Senate Comm. on Labor and Public Welfare, 90th Cong., lst Sess. 22, 25 (1967) (statement by Sen. Murphy); id. at 29 (statement by Sen. Smather).

19. Older Americans Act of 1965, 42 U.S.C. $\$ \S 3001-3055$ (1982); Manpower Development and Training Act of 1962, Pub. L. No. 87-415, 76 Stat. 23 (codified as amended in scattered sections of 42 U.S.C.).

20. Exec. Order No. $11,141,3$ C.F.R. 112 (1964), reprinted in 5 U.S.C. $\$ 3301$ (1982).

21. U.S. Dep'T of Labor, Report to THE Congress on Age Discrimination in EMPLOYMENT Under Section 715 of the Civil Rights ACt of 1964 (1965) [hereinafter U.S. Dep't of Labor Report].

22. H.R. ReP. No. 805, 90th Cong., 1st Sess. 2 (1967); S. Rep. No. 723, 90th Cong., 1st Sess. 1 (1967).

23. H.R. REP., No. 805, supra note 22, at 2; S. REP. No. 723, supra note 22, at 1.

24. Special Message, supra note 17. 


\section{A. Prohibitions}

The prohibitory language of the ADEA is almost identical to that of Title VII. ${ }^{25}$ Under the ADEA, ${ }^{26}$ it is unlawful for an employer

(1) to fail or refuse to hire or to discharge any individual or otherwise discriminate against any individual with respect to his compensation, terms, conditions, or privileges of employment, because of such individual's age;

(2) to limit, segregate, or classify his employees in any way which would deprive or tend to deprive any individual of employment opportunities or otherwise adversely affect his status as an employee, because of such individual's age; or

(3) to reduce the wage rate of any employee in order to comply with this chapter.

The Act, amended in 1978, now with few exceptions ${ }^{27}$ protects all federal employees over the age of 40 as well as non-federal employees between the ages of 40 and 70.28 The ADEA does not prohibit the compulsory retirement of a bona fide executive or high-level policymaker for the two-year period immediately before planned retirement if that individual will be entitled to nonforfeitable annual retirement benefits of at least $\$ 54,000 .^{29}$

\section{B. Defenses}

There are five basic defenses to an ADEA action:

(1) when age is a bona fide occupational qualification (BFOQ);30

(2) when the differentiation is based on reasonable factors other than age; ${ }^{31}$

(3) when the differentiation is necessary to observe the terms of a bona fide seniority system;32

(4) when the differentiation is necessary to observe a bona fide employee benefit plan; ${ }^{33}$ or

(5) when discharge or discipline is for "good cause."34

The BFOQ defense is applicable when age has been made an express criterion "reasonably necessary to the normal operation of the particular business." 95 By its terms, the BFOQ defense applies only in instances of

25. Under Title VII, 42 U.S.C. $\$ 2000 \mathrm{e}-2$ (a) (1982), it is unlawful

(1) to fail or refuse to hire or to discharge any individual, or otherwise to discriminate against any individual with respect to his compensation, terms, conditions, or privileges of employment, because of such individual's race, color, religion, sex, or national origin; or

(2) to limit, segregate, or classify his employees or applicants for employment in any way which would deprive or tend to deprive any individual of employment opportunities or otherwise adversely affect his status as an employee, because of such individual's race, color, religion, sex, or national origin.

26. 29 U.S.C. $\$ 623(\mathrm{a})$ (1982).

27. The exceptions to the rule are for firefighters, air traffic controllers, law enforcement officers, and certain other designated employees. 5 U.S.C. $\$ 8335$ (1982).

28. 29 U.S.C. $\$ 631(\mathrm{a}), 633 \mathrm{a}(\mathrm{a})$ (1982).

29. Id. $\$ 631$ (c)(1) (1982).

30. Id. $\S 613(\mathrm{f})(2)(1982)$.

31. Id.

32. Id. \& 623(f)(2).

33. Id.

34. Id. $\S 623(\mathrm{f})(3)$.

35. Id. \& 623(f)(1) (Supp. III 1985). 
disparate treatment. Regulations and court decisions provide examples of circumstances in which this defense is valid, indicating that the criteria must be reasonably necessary to the "essence" of the business, ${ }^{36}$ and that the employer must have a factual basis for believing that all, or substantially all, persons within the protected class would be unable to perform the job's duties safely and efficiently, or that to determine individual ability of persons over the age limit would be either impossible or impracticable. ${ }^{37}$

Unlike the BFOQ defense, the ADEA's provision for differentiation based on "reasonable factors other than age" seems to apply where there has been disparate impact as well as where there has been a charge of disparate treatment. The interpretative guidelines from the Secretary of Labor describing fact situations that would and would not support a finding of "reasonable factors" suggest that the test is equivalent to the "business necessity" or "job relatedness" tests under Title VII. ${ }^{38}$ Like those defenses, the "reasonable factors other than age" defense is properly seen as a denial of the plaintiff's prima facie case and is thus equivalent to an assertion of no discrimination when the action is based on the disparate treatment doctrine. Physical fitness requirements, education requirements, and quantity and quality of production are examples of factors discussed in the interpretative guidelines. ${ }^{39}$

The defenses recognizing bona fide seniority systems and employee benefit plans require that the plan in question not be designed to evade the purposes of the ADEA. ${ }^{40}$ The section that permits discharge or discipline of employees for good cause is similar to the provision allowing differentiation on "reasonable factors other than age." 41

\section{III}

\section{DISPARATE IMPACT}

Most of the actions brought under the ADEA have been disparate treatment cases involving white males who have not been hired or who have been fired from their jobs. ${ }^{42}$ A few cases have involved combined age and race or age and gender discrimination claims. ${ }^{43}$ In one recent age and

36. Dothard v. Rawlinson, 433 U.S. 321,333 (1977) (quoting Diaz v. Pan American World Airways, 442 F.2d 385, 388 (5th Cir.), cert. denied, 404 U.S. 950 (1971)); Usery v. Tamiami Trail Tours, Inc., 531 F.2d 224, 236 (5th Cir. 1976).

37. Arritt v. Grisell, 567 F.2d 1267 (4th Cir. 1977); see also Phillips v. Martin Marietta Corp., 400 U.S. 542 (1971).

38. 29 C.F.R. $\$ 860.103(1985)$.

39. Id.

40. 29 U.S.C. $\S 623(\mathrm{f})(2)(1982)$.

41. Id. $\$ 623(\mathrm{f})(1)$.

42. See Blumrosen, Book Review, 12 Seton Hall L. Rev. 186, 192 (1981) (arguing that application of the disparate impact theory would slow the progress of affirmative action for minorities and women since white males in their fifties and sixties are the principal beneficiaries of the ADEA); see also, cases cited infra note 48 (except Smithers and Smith).

43. Stearns v. Consolidated Management, Inc., 747 F.2d 1105 (7th Cir. 1984); Sweat v. Miller Brewing Co., 708 F.2d 655 (1 lth Cir. 1983); Scharnhorst v. Independent School Dist., 686 F.2d 637 (8th Cir. 1982), cert. denied, 462 U.S. 1109 (1983). 
gender-based case ${ }^{44}$ and in future challenges to employment decisions involving displaced homemakers, however, the use of the disparate impact doctrine may be essential to further the purpose of the ADEA-elimination of employment discrimination based on illusory rather than real problems. ${ }^{45}$

In 1971, the United States Supreme Court held in Griggs v. Duke Power Co. ${ }^{46}$ that facially neutral employment practices resulting in discriminatory or disparate impact violated Title VII of the Civil Rights Act of 1964. Two years later, in McDonnell Douglas Co. v. Green, ${ }^{47}$ the Court set forth the requirements of a prima facie case of discrimination based on disparate treatment under Title VII. Nine circuits have decided that the disparate treatment standards announced in McDonnell Douglas are applicable to an ADEA action. ${ }^{48}$ Only four of those circuits, however, have adopted the Griggs disparate impact doctrine in ADEA actions. ${ }^{49}$

Although Lorillard $v$. Pons ${ }^{50}$ was concerned with a procedural issue (the provision of a jury trial in ADEA actions) and declined to follow Title VII's lead in the matter, courts ${ }^{51}$ and commentators ${ }^{52}$ that recognize either disparate treatment or disparate impact generally cite Lorillard for the proposition that the substantive prohibitions of the ADEA were "derived in haec verba from Title VII" and that there are "important similarities" in the purposes and substantive provisions of the two statutes. ${ }^{53}$ Courts and commentators that have not adopted both the disparate impact and the disparate treatment doctrines have pointed to the different legislative histories behind Title VII and ADEA,54 the different natures of age discrimination and race or religious discrimination, ${ }^{55}$ the source of the disparate impact doctrine, ${ }^{56}$ and the language of the $\mathrm{ADEA}^{57}$ as support for not extending the doctrine to ADEA actions.

44. Haskins v. Secretary of HHS, 35 Fair Empl. Prac. Cas. (BNA) 256 (W.D. Mo. 1984).

45. For a discussion of the purpose of the ADEA, see supra note 21 and accompanying text.

46. 401 U.S. 424 (1971).

47. 411 U.S. 792, 802 (1973).

48. Sutton v. Atlantic Richfield Co., 646 F.2d 407 (9th Cir. 1981); Stanojev v. Ebasco Serv., Inc. 643 F.2d 914 (2d Cir. 1981); Smith v. University of N.C., 632 F.2d 316 (4th Cir. 1980); Kephart v. Institute of Gas Technology, 630 F.2d 1217 (7th Cir. 1980), cert. denied, 450 U.S. 959 (1981); Smithers v. Bailar, 629 F.2d 892 (3rd Cir. 1980); Marshall v. Sun Oil Co., 605 F.2d 1331 (5th Cir. 1979); Loeb v. Textron, Inc., 600 F.2d 1003 (1st Cir. 1979); Kentroti v. Frontier Airlines, Inc., 585 F.2d 967 (10th Cir. 1978); Cova v. Coca-Cola Bottling Co., 574 F.2d 958 (8th Cir. 1978).

49. See Leftwich v. Harris-Stowe State College, 702 F.2d 686 (8th Cir. 1983); Allison v. Western Union Tel. Co., 680 F.2d 1318 (11 th Cir. 1982); Douglas v. Anderson, 656 F.2d 528 (9th Cir. 1981); Geller v. Markham, 635 F.2d 1027 (2d Cir. 1980), cert. denied, 451 U.S. 945 (1981).

50. 434 U.S. 575 (1978).

51. E.g., Hodgson v. First Fed. Sav. \& Loan, 455 F.2d 818, 820 (5th Cir. 1972) ("With a few minor exceptions, the prohibitions of [ADEA] are in terms identical to those of Title VII . . except that 'age' has been substituted for race, color, religion, sex or national origin.").

52. See, e.g., Player, supra note 9 , at 623.

53. Lorillard, 434 U.S. at 584.

54. E.g., Note, supra note 9 , at 844.

55. Id. at 850; Schuck, Age Discrimination Revisited, 57 ChI. [-] Kent L. Rev. 1029 (1981); Note, The Age Discrimination in Employment Act of 1967, 90 HARv. L. REv. 380, 383 (1976).

56. E.g., Note, supra note 9 , at 848 .

57. Id. at 842 . 
In a recent case under section 504 of the Rehabilitation Act of 1973,58 the Supreme Court considered whether disparate impact analysis was permissible when considering discrimination against the handicapped. ${ }^{59}$ The Court found for the agency charged with discrimination because the impact in question was not the type that would have been found discriminatory under a disparate impact analysis. However, the Court did assume, without deciding, that section 504 reached "at least some conduct that has an unjustifiable impact upon the handicapped."'60 The Supreme Court's decision supports reasoning by some federal district courts ${ }^{61}$ that even if disparate impact is an acceptable theory for analysis of some discrimination cases, there must be a case-by-case analysis to determine when to apply the doctrine. In the context of section 504, at least, the Court seems to indicate that the analysis depends on a balance between giving effect to statutory objectives and administrative efficiency. ${ }^{62}$ If that is the balance to be made in each disparate impact case, both legislative purpose and procedural requirements need to be examined.

One argument made against adoption of the disparate impact theory in ADEA cases is that its application would likely prove too unwieldy. A significant factor would be that ADEA cases, unlike Title VII cases, permit trial by jury. ${ }^{63}$ If, however, as is generally accepted in Title VII and ADEA cases, and assumed in this article, disparate impact either does or does not apply to a particular statutory scheme (a proposition not supported by the section 504 case), the case-by-case balance should not be a significant impediment to its utilization.

\section{A. Legislative History}

In a report made in response to a directive contained in the Civil Rights Act of 1964, the Secretary of Labor noted that although there were fifty-two million Americans between the ages of forty and sixty-four, half of all jobs were closed to workers over fifty-five years of age and one-fourth to workers over forty-five; among unemployed workers generally, over one-fourth were forty-five or older and among long-term unemployed, one-half were in that age category. ${ }^{64}$ In addition, the report stated that of the billion dollars in unemployment insurance paid out each year, three-fourths went to persons over forty-five. ${ }^{65}$ President Johnson, in his message to Congress recommending the consideration and passage of the ADEA, spoke of

58. 29 U.S.C. $\$ 794(1982)$.

59. Alexander v. Choate, 469 U.S. 287 (1985).

60. Id. at 299.

61. See, e.g., Blackwell v. Sun Elec. Corp., 696 F.2d 1176, 1187 (6th Cir. 1983); Murphy v. American Motors Sales Corp., 410 F. Supp. 1403, 1405 (N.D. Ga. 1976), modified on other grounds, 570 F.2d 1226 (5th Cir. 1978).

62. Alexander, 469 U.S. at 299.

63. This objection was one made by members of the North Carolina defendants' bar attending this Law and Contemporary Problems symposium.

64. U.S. DEP'T OF LABOR REPORT, supra note 21.

65. Id. 
"[h]undreds of thousands not yet old, not yet voluntarily retired, [who] find themselves jobless because of arbitrary age discrimination."66

The severity of the impact due to unemployment on the older worker has been a concern in ADEA actions as well as in congressional hearings. One court, in ruling on the availability of damages for pain and suffering in a termination case, recognized that the psychological and physiological problems of aging, coupled with arbitrary and illegal discharge, "can take a dramatic toll."' 67 An amicus brief filed by the American Medical Association discussing mandatory retirement referred to "loss of status, lack of meaningful activity, fear of becoming dependent, and ... isolation" as factors impacting the health of older unemployed workers. ${ }^{68}$

The Civil Rights Act of $1964,{ }^{69}$ on the other hand, was a direct response to the civil unrest of the early 1960's. Its passage, like the passage of the Voting Rights Act of $1965^{70}$ and the Fair Housing Act of $1968,{ }^{71}$ was a response, much akin to an apology, for acts of violence by whites in retaliation for moderate civil rights activity. ${ }^{72}$ Unlike discrimination on account of race, the original object of Title VII-discrimination on account of age-was not perceived to be a widespread problem. In fact, attempts to include a prohibition against discrimination on account of age in Title VII failed..$^{73}$ The ADEA, when passed, relied on the enforcement procedures of the Fair Labor Standards Act. ${ }^{74}$ Whether these differences in the legislative histories of Title VII and the ADEA justify differing standards of proof is a part of the debate that is the focus of this article. Whether the different character of discrimination based on age requires different treatment from that afforded Title VII plaintiffs is an additional concern.

\section{B. The Nature of Discrimination and the Source of the Disparate Impact Doctrine}

Discrimination against a person on the basis of age is generally not based on bigotry, but rather on a stereotyping of individuals' abilities based on a mistaken perception of the abilities of an entire class of older workers. Attempts to distinguish this type of discrimination from distinctions made among individuals based on personal prejudice or emotion has led some courts and writers to conclude that legal responses to the problems should be

66. Special Message, supra note 17 , at 37 .

67. Rogers v. Exxon Research \& Eng'g Co., 404 F. Supp. 324, 329 (D.N.J. 1975), vacated on unrelated grounds, 550 F.2d 834 (3d Cir. 1977), cert. denied, 434 U.S. 1022 (1978).

68. Brief for the American Medical Association as Amicus Curiae, at 4, Weisbrod v. Lynn, 383 F. Supp. 933 (D.D.C. 1974), aff'd, 420 U.S. 940 (1975).

69. 28 U.S.C. $\$ 1447 ; 42$ U.S.C. $\$ \& 1971,1975 \mathrm{a}-1975 \mathrm{~d}, 2000 \mathrm{a}-2000 \mathrm{~h}-6$ (1982).

70. 42 U.S.C. $\$ \S 1971,1973-1973 b b(1982)$

71. 42 U.S.C. $\$ \$ 3601-2619$ (1982).

72. A. LARSON \& L. LARSON, supra note $11, \$ 66.44$ (citing public reaction to the murder of three seminary students, the shooting of James Meridith, and the murder of Viola Liuzzo as contributing to the passage of the three Acts).

73. See H.R. 16972, 93d Cong., 2d Sess. (1974); H.R. 17383, 93d Cong., 2d Sess. (1974).

74. 29 U.S.C. $\$ 626$ (a) (1982). 
different. ${ }^{75}$ Others have characterized Griggs v. Duke Power Co. ${ }^{76}$ and its progeny as focusing on redress for past discrimination, noting its inapplicability to age discrimination since ostensibly the present-day older worker was actually the beneficiary of age discrimination when younger. ${ }^{77}$ They argue that the disparate impact doctrine is applicable only in instances that reflect a blend of circumstances-a past history of discrimination, either by the defendant, the industry, or society, and facially neutral criteria that serve to perpetuate the effects of that past discrimination. There is little support for such a limitation either in Griggs or in Title VII disparate impact cases since Griggs, 78 and there is no such evidentiary requirement in presenting Title VII claims. Even if one were to concede the impossibility of lifting the disparate impact doctrine completely from Title VII to overlay the ADEA without reexamining the different "kinds" of discrimination prohibited under the two statutes, nothing dictates that past institutional discrimination be the focus of a reexamination. ${ }^{79}$

\section{Language of the ADEA}

The failure of courts to cite specific sections of the ADEA when adopting a disparate impact analysis gives rise to one argument against the use of the disparate impact doctrine in ADEA cases. The claim is that there is some ambiguity in the statute's language that, although it could be read to allow disparate impact, provides for only disparate treatment analysis when read grammatically. ${ }^{80}$ Such an argument is questionable, particularly when

75. Massachusetts Bd. of Retirement v. Murgia, 427 U.S. 307, 313 (1976) (per curiam); U.S. DeP'T of LABOR, supra note 21 , at 2, 6; A. LARSON \& L. LARsON, supra note 11, at $\$ 66.25$; Note, supra note 55 , at $383-88$.

76. 401 U.S. 424 (1971).

77. Laugesen v. Anaconda Co., 510 F.2d 307 (6th Cir.), cert. denied, 422 U.S. 1045 (1975).

78. See, e.g., Dothard v. Rawlinson, 433 U.S. 321 (1977) (applying the Griggs disparate impact analysis to sex discrimination).

79. In McDonnell Douglas Corp. v. Green, 411 U.S: 792, 800.06 (1973), decided two years after Griggs, the Supreme Court approved the disparate treatment doctrine under Title VII, while affirming the use of the disparate impact doctrine in Griggs. Language in McDonnell Douglas that attempts to distinguish the facts of that case from Griggs, thus requiring the use of the disparate treatment doctrine, could be used to support the argument that the disparate impact doctrine is applicable only where there is evidence of prior disadvantage "resulting from forces beyond their [minority's] control." Id. at 806 .

80. Noting that Geller v. Markham, 635 F.2d 1027 (2d Cir. 1980), cert. denied, 451 U.S. 945 (1981), failed to cite a specific section of the ADEA to support the application of the disparate impact doctrine, the author in Note, supra note 9 , at 842-48, examines ADEA $\S \$ 4(a)(2)$ and 4(f)(1), seeking authorization for adoption of the disparate impact doctrine in the express language of those provisions. That author concludes that because of the ambiguity involved in determining the object of the modifier "because of such individual's age" in $\$ 4(\mathrm{a})(2)$, there are at least two interpretations to be given the clause "to limit, segregate, or classify his employees in any way which would deprive or tend to deprive any individual of employment opportunities or otherwise adversely affect his status as an employee, because of such individual's age." Note, supra note 9, at 842 (quoting 29 U.S.C. $\$ 623(\mathrm{a})(2)(1976)$ ). She further concludes that only one such interpretation is grammatically correct, the one that supports disparate treatment only. Id. at $\mathbf{8 4 3 .}$

To support her interpretation, the author also looks at $\$ 4(a)(1)$ of the ADEA, a section that she claims was constructed identically to $\$ 4(\mathrm{a})(2)$, although the point of the comparison is to show that there is not such ambiguity in $\S 4(\mathrm{a})(1)$, a section that she feels authorizes only disparate treatment claims. Id. She notes that since $\$ 4(\mathrm{a})(2)$ addresses only "employees" and $\S 4(\mathrm{a})(1)$ addresses 
recognizing that the structure of the pertinent sections of the ADEA were derived directly from Title VII. ${ }^{81}$

Another argument that the language of the ADEA forbids the disparate impact doctrine's adoption suggests that the language of section $4(f)(1)$, permitting differentiation "based on reasonable factors other than age," actually precludes disparate impact claims. ${ }^{82}$ County of Washington $v$. Gunther, ${ }^{83}$ a Supreme Court opinion interpreting a Title VII amendment barring certain gender-based wage discrimination claims, is cited as support for this contention. ${ }^{84}$ That amendment, in effect, would not require equal pay for equal work under Title VII in all cases. Title VII's failure to provide for an affirmative defense of a differential based on "factors other than gender," while providing for the other affirmative defenses authorized by the Equal Pay Act, is necessary according to the Court to avoid "significant consequences for Title VII litigation." 85 The argument alleges that since it could be inferred that equal pay claims were limited to use of the disparate treatment doctrine, by analogy, section $4(f)(1)$ was limited in the same manner. ${ }^{86}$ The Court's actual language, however, addressed the Equal Pay Act's restriction to gender discrimination compensation claims as opposed to the entire gamut of Title VII objects. ${ }^{87}$ Citing Griggs, the Court reiterated the broad scope of Title VII: "Title VII's prohibition of discriminatory employment practices was intended to be broadly inclusive, proscribing 'not only overt discrimination but also practices that are fair in form, but discriminatory in operation." "88

\footnotetext{
"individuals," it would be anomalous to allow a disparate impact claim for everyone except applicants, the group she alleges are the "most common claimants under the disparate impact doctrine." Id.

In other words, the claim is that $\S \S 4(a)(1)$ and $4(a)(2)$ are constructed identically, but $\S 4(a)(1)$ does not contain the ambiguity of $\S 4(\mathrm{a})(2)$, and, if read correctly, authorizes only disparate treatment. Further, since $\S 4(\mathrm{a})(2)$ applies only to existing employees and $\S 4(\mathrm{a})(1)$ applies to everyone, an anomaly exists: allowance of disparate impact and disparate treatment claims for existing employees, but only disparate treatment claims for applicants.

The conclusion of the argument about $\S 4(a)(2)$ 's lack of specific support for the disparate impact doctrine cites the lack of legislative history addressing the provision. Id. at 843-44. The author observes that "[a]pparently the provision was simply borrowed verbatim from Title VII," and that Title VII was not originally intended to authorize disparate impact claims. Id. Such an analysis fails to acknowledge the Supreme Court's interpretation in Griggs of congressional acceptance of the disparate impact theory under Title VII. Later in the note, the author discusses the rationale of the disparate impact doctrine, arguing that Griggs only applies when the discrimination complained of serves to " 'freeze' the status quo of prior discriminatory employment practices." Id. at 848 (quoting Griggs v. Duke Power, 401 U.S. 424, 430 (1971)). Courts have stated that the language of the ADEA was derived from Title VII.

81. Oscar Mayer \& Co. v. Evans, 441 U.S. 750, 751 (1979); Lorillard v. Pons, 434 U.S. 575, 584 (1978).

82. Note, supra note 9 , at $844-48$.

83. 452 U.S. 161 (1981).

84. Note, supra note 9 , at 845 .

85. County of Washington v. Gunther, 452 U.S. 161, 170 (1981).

86. Such an analysis, contained in Note, supra note 9 , at $844-48$, though not persuasive for this author, was repeated by one of the participants in the Law and Contemporary Problems symposium upon which this issue is based, and it evidently enjoys more than minimal support.
}

87. 452 U.S. at 181 .

88. Id. at 170 (quoting Griggs v. Duke Power Co., 401 U.S. 424, 431 (1971)). 


\section{Disparate Treatment versus Disparate IMPaCt}

The disparate treatment doctrine would require plaintiffs to prove that the discrimination they suffered was purposeful, and not merely the result of otherwise neutral factors. ${ }^{89}$ The Supreme Court's alleged source for both the disparate treatment and the disparate impact theories contributes to the confusion surrounding the question of when the theories should be employed. In Griggs v. Duke Power Co., a case involving employment tests, the Court, in examining the pertinent section of Title VII, read the statute to permit disparate impact analysis. ${ }^{90}$ Conversely, in International Brotherhood of Teamsters $v$. United States, ${ }^{91}$ a seniority case, the Court indicated that the same section required proof of disparate treatment. Furnco Construction Corp. $v$. Waters, ${ }^{92}$ a Title VII challenge claiming both disparate impact and disparate treatment, provided the Court an opportunity to set forth the standards for determining when an action should embrace the disparate treatment doctrine and when it should employ the disparate impact doctrine. The Court did not seize its opportunity. Instead, the majority used only a disparate treatment analysis without an adequate explanation for its choice. Differences in the defenses available and in the nature of the burden of proof once those defenses have been raised could cause the standard applied to be significant in the outcome of the litigation. ${ }^{93}$ Adoption of the disparate impact as well as the disparate treatment doctrine in ADEA cases, therefore, could have a significant impact on a plaintiff's ability to recover damages.

\section{$\mathrm{V}$}

\section{DisPlaced HOMEMAKERS}

A "displaced homemaker" is a woman who had been dependent on her spouse for income, but lost that income through divorce, separation, desertion, or the disablement or death of her husband.94 In today's society, older displaced homemakers are in a unique position because of both sex and age. They have acceded to societal expectations by devoting their energy to family-building rather than career-building, but when forced to support themselves (and frequently their families) they find that their careers as chauffeurs, nurses, tutors, social secretaries, hostesses, gardners, laundresses, financial managers, counselors, and general handymen count for naught in the "real" world. Volunteer activities that may have required complex

89. McDonnell Douglas Corp. v. Green, 411 U.S. 792 (1973).

90. 401 U.S. 424,432 (1971).

91. 431 U.S. $324,345-47$ (1977).

92. 438 U.S. 567 (1978).

93. Belton, Burdens of Pleading and Proof in Discrimination Cases: Toward a Theory of Procedural Justice, 34 VAND. L. Rev. 1205, 1231 (1981) (claims that Furnco is notable because the Supreme Court failed to suggest standards for determining when to apply the disparate impact or the disparate treatment doctrine).

94. L. Shields, Displaced Homemakers: Organizing for a New life at ix (1981). 
administrative and organizational skills likewise are not taken into account in most hiring decisions. The effect on older women who have met traditional societal expectations in their "prime" years is one of discrimination. Neither Title VII nor the ADEA as now applied can deal adequately with this phenomenon.

Congress has not been entirely insensitive to the plight of the displaced homemaker. Since 1977, at least six bills addressing the issue have been introduced. ${ }^{95}$ The 1978 amendments to the Comprehensive Employment and Training Act (CETA) provided for job counseling, training and placement, health education and counseling, financial management services, educational services, and legal counsel and referral specifically for displaced homemakers. ${ }^{96}$ Unfortunately, the successor to CETA, the Job Training Partnership Act of 1982,97 established a complicated eligibility system, seemingly limiting funds available to the displaced homemaker; other legislation has not afforded any significant relief.

Programs derived from legislation such as CETA that have addressed the problem of the displaced homemaker have resembled a benign version of "blame the victim," concentrating on training, financial management services, job counseling and the like. They have been helpful in that displaced homemakers have enjoyed resources that before the late 1980's were not available on any widespread basis or in any systematic way, but they are not helpful to women who have skills but not jobs. As noted above, the 1982 successor to CETA, the Job Training Partnership Act, has, because of its implementation system, severely limited even those resources. ${ }^{98}$ The problem of the displaced homemaker will remain for some time to come. Uncertainties about the future of social security compensation and the likelihood of continuing inflation further exacerbate the problem.

The older displaced homemaker presents special problems in society. Her younger counterpart often finds it easier to make the transition to sole provider for herself and her dependents. Training opportunities available to younger workers often are not suitable for or available to the older displaced homemaker. Although some older women have resources such as insurance payments, social security benefits, alimony, and child support, it is estimated that $23.6 \%$ of all widows live below the poverty level, ${ }^{99}$ and fewer than $67.4 \%$

95. H.R. 2090, 98th Cong., 1st Sess. (1983); H.R. 2127, 98th Cong., 1st Sess. (1983); H.R. 3554, 98th Cong., 1st Sess. (1983); H.R. 835, 97th Cong., 1st Sess. (1981); H.R. 10272, 94th Cong., 1st Sess. (1975); H.R. 28, 95th Cong., 1st Sess. (1977).

96. The relevant provisions of the Comprehensive Employment and Training Act Amendments of 1978, Pub. L. No. 95-524, 92 Stat. 1909, included "displaced homemakers" in the list of special groups with particular labor market disadvantages, $i d$. $\$ 301$ (a)(1), and provided "financial assistance to conduct programs to provide employment opportunities and appropriate training and supportive services," id. $\$ 301$ (b)(1)(A).

97. 29 U.S.C. $\$ 1501$ (1982).

98. Smith, JTPA Is Missing Displaced Homemakers and Older Women, in 1985 JoBS WATCH Alert 3.

99. U.S. Bureau of the Census, Current Population Reports, Ser. P-60, No. 144, Characteristics of the Population Below the Poverty Level: 1982, at 92 (1984) (information contained in table 21 ). 
of divorcees receive alimony and child support. ${ }^{100}$ In addition, persons who have not recently been employed are not eligible for unemployment compensation. Women whose husbands have deserted them frequently are unable to locate either their husbands or their husbands' assets, and women whose husbands are disabled face increased expenses coupled with decreased income, more often than not causing severe financial strain.

A displaced homemaker has contributed to the support of her family through work without compensation or the protections normally accompanying loss of compensation. Although men are widowed, deserted, divorced, and left with disabled spouses as well, as a group, they are not nearly as likely as women to suffer the financial or emotional consequences accompanying the loss of a partner's income. Four-tenths of one percent of all men work exclusively as homemakers as opposed to $30.6 \%$ of all women. ${ }^{101} \mathrm{~A}$ man is therefore almost 100 times less likely to qualify as a displaced homemaker than a woman. Since the problem affects women almost exclusively, it takes on the cloak of a "woman's problem." To the extent that women suffer employment discrimination because of their displaced status, it becomes a matter of gender discrimination.

Although fewer women are devoting their years between ages twenty and forty exclusively to work within the home, approximately ten percent still do stay home. ${ }^{102}$ Divorces among women over forty have risen from 2.6 million in 1977 to 3.5 million in 1983.103 The average woman's life expectancy is now 78.2 years compared to the average man's 70.9 years. ${ }^{104}$ To the extent older women suffer employment discrimination because of their displaced status more than do younger women, the matter has also become one of age discrimination.

If this society values the choice made by women to remain in the home rather than to seek outside employment, it implicitly assumes some responsibility to see that the women who make that choice and who are subsequently disadvantaged because of it do not suffer for it. Some women can plan for financial security through adequate insurance or the transfer of assets during marriage. Many families are unable to do so, however, and no matter how much planning they do, it will often be necessary for the woman to seek employment if she suddenly finds herself responsible for her own support and the support of dependents. Existing legislation and common law

100. U.S. Bureau of the Census, Current Population Reports, Series P-23, No. 124, Child Support And Alimony: 1981 (Advance RePort), at 2 (1983) (table A). Only $43.5 \%$ receive the full amount awarded. Id.

101. Bureau of Labor Statistics, U.S. Dep't of Labor, 31 Employment and Earnings, No. 1, at 196 (1984) (table 35).

102. Id. at 9 (table A-4). In December, 1984, of the $93,164,000$ employable women (civilian/noninstitutional) 16 years and older, 9,651,000 of those 39 years and under considered themselves to be not in the labor force because of "housekeeping duties."

103. U.S. Bureau of the Census, Current Population Reports, Series P-20, No. 323, Marital Status and Living Arrangements: March 1977, at 7 (1978) (information contained in table 1).

104. National Center for Health Statistics, Advance Report of Mortality Statistics, No. 9 \& Supp., Advance Report of Mortality Statistics: 1982 at II (1984) (table 3). 
theories have been unhelpful; women have faced discrimination because after choosing to work in the home, they have encountered employers who have disregarded the skills gained from that experience.

Use of legal theories has stymied the displaced homemaker. One such theory, for example, requires that once a plaintiff has shown a prima facie case of discrimination, the defendant-employer has the opportunity to prove some legitimate business reason for the failure to hire. The reason most often cited for failure to hire the woman who has not been in the workplace for fifteen to twenty years is lack of recent experience, a job requirement regarded as valid by society. The task confronting displaced homemakers, then, is the development of evidence that they possess the requisite skills and experience for jobs as well as evidence that employers' refusal to hire on the basis of lack of experience is pretextual or not job-related.

Displaced homemakers have received attention in this article and elsewhere because they are a discrete group with definite traits: they cannot easily be held to have made truly voluntary choices leading to their depressed circumstances. In addition, the displaced homemaker, unlike other older women, has lost financial support that would make her financially secure. The employment problems facing the displaced homemaker, however, also face many older women. Statistics show that women are much more likely than men to interrupt their careers outside the home for care of children or other family members. Thus, older women are as likely as displaced homemakers to face the same discrimination when returning to the labor force.

In a recent federal district court opinion, Haskins v. Secretary of $H H S,{ }^{105}$ a woman had been out of the full-time labor force for over fourteen years, although she was not a displaced homemaker within the generally accepted meaning of that term. During that fourteen years, she had been a mother, the wife of a foreign service officer, a volunteer in the Montessori movement, and a part-time VISTA administrator. She was also a volunteer with a children's community theater, a neighborhood group, and a university music conservatory. When she returned to full-time work for the federal government, her rating was GS-10, as opposed to the GS-13 she held prior to leaving. Her salary was $\$ 1300$ a year less than it had been fourteen years before. After applying and not being hired for a GS-14 position, she filed suit claiming age and gender discrimination because the employer's use of a "recency factor" caused the panel rating her application not to consider any experience more than ten years old.

Plaintiff presented uncontroverted expert testimony that use of a recency factor discriminates against women since they are more likely than men to interrupt careers to care for small children, and that it further discriminates against older women since women who were in their twenties and thirties in the 1950's and 1960's tended to become homemakers more frequently than

105. 35 Fair Empl. Prac. Cas. (BNA) 256 (W.D. Mo. 1984). 
do their present-day counterparts. ${ }^{106}$ The court found that the use of the recency factor discriminated disproportionately against older women and thus had a disparate impact, both as to gender and as to age. ${ }^{107}$

Citing Griggs, the court shifted the burden of going forward to the defendant, who had to show that the recency factor was related to the performance of the job for which plaintiff applied. It was found that the lack of consideration of her older "valuable experience" was "arbitrary and capricious." 108 Plaintiff thus established a prima facie gender and age discrimination case. ${ }^{109}$

Situations encountered by the displaced homemaker are similar to those faced by the plaintiff in Haskins, but are often decidedly more grim. Although the opinion in Haskins supports the illegality of discounting older prior paid experience-a problem for some displaced homemakers-many face the complete disregard of uncompensated work, and are therefore labeled unqualified or unskilled. In applying the disparate impact analysis employed in Haskins to the worst case scenario (a sixty-year-old displaced homemaker who has never worked outside the home), courts and jurors might reasonably conclude that this lack of "formal" experience was reasonably related to job performance and essential to the business. Therefore, even though a court might find age and gender discrimination, as in Haskins, a potential employer could rebut the prima facie disparate impact case by showing the relationship between prior uncompensated experience and the job sought.

\section{A. Disparate Impact and the Displaced Homemaker}

As fewer women choose to forgo work outside the home, even while their children are young, proving disparate impact based on gender discrimination will be more difficult. The discrimination will nonetheless affect older women disproportionately. Use of the disparate impact doctrine under the ADEA in cases where the affected woman is older would seem to be essential to recovery. The Haskins court accepted the application of the doctrine without discussion, combining Title VII and the ADEA into one consideration of "discrimination."110 Until the Supreme Court makes a more definitive pronouncement than a denial of certiorari in a disparate impact case, some courts will struggle with the application of the doctrine in ADEA actions.

Courts that claim to use a case-by-case approach ${ }^{111}$ when considering the disparate impact doctrine in age discrimination cases have been unclear about

106. Id. at 257-61.

107. Id. at 262.

108. Id. at 263.

109. Id. at 262.

110. Id. at 263.

111. Blackwell v. Sun Elec. Corp., 696 F.2d 1176 (6th Cir. 1983); Ackerman v. Diamond Shamrock Corp., 670 F.2d 66 (6th Cir. 1982); Gabriele v. Chrysler Corp., 573 F.2d 949, 953 (6th Cir. 1978), vacated on other grounds, 442 U.S. 908 (1979); Murphy v. American Motors Sales Corp., 410 F. Supp. 1403, 1405 (N.D. Ga. 1976), modified on other grounds, 570 F.2d 1226 (5th Cir. 1978); Laugesen v. Anaconda Co., 510 F.2d 307 (6th Cir. 1975), cert. denied, 422 U.S. 1045 (1975). 
the factors considered. One can assume that courts ordinarily examine the facts of the case in light of the three factors considered in section II above: the legislative purpose of the ADEA, the nature of the discrimination, and the sources of the doctrine. ${ }^{112}$ Arguments that the statute's language fails to support or precludes the doctrine have not fared well even when courts have not applied it; recognition that the doctrine is in haec verba with Title VII has precluded that particular argument. ${ }^{113}$

1. Legislative Purpose. Much of the legislative history of the ADEA focused on the older breadwinner who had been discharged and found himself physiologically, psychologically, and financially debilitated because of his unemployment. The displaced homemaker is likewise "discharged." She can no longer remain in the position that she has held over the years and she too suffers physiological, psychological, and financial disaster. Her financial, educational, and emotional resources often are more limited than those of her counterpart who has been employed recently outside the home. ${ }^{14}$ Instead of unemployment compensation, welfare assistance is often her only alternative, and then only if she has children living at home who are under the age of eighteen. ${ }^{115}$ The costs to society and to the individual are high in terms of money and human resources and the ADEA's objective of having employment decisions made on the basis of real rather than illusory factors is not met.

\section{The Nature of Age Discrimination and the Source of the Disparate Impact Doctrine.} The discrimination that the displaced homemaker suffers, like age discrimination in general, is not based on bigotry, but rather on the stereotype that a woman has no skills if she has not worked outside the home. Because her experience is not often evaluated in terms of what is involved in performing individual tasks, there is an assumption that she does not possess the requisite skills for a particular job. Her disadvantage is akin to the disadvantage many minorities suffer when employers evaluate characteristics that result from prior societal actions and use them to distinguish applicants or workers from persons who have not been subject to placement in those same societal roles.

As indicated above, some courts and commentators would have the disparate impact doctrine apply only to Griggs-type situations involving a history of discrimination against the protected class by either the employer, the industry, or society, as well as facially neutral criteria that serve to perpetuate the effects of that past discrimination. ${ }^{116}$ Under such a view, displaced homemakers might still be entitled to use the disparate impact

112. See supra text accompanying notes 65-82.

113. See supra text accompanying notes $44-45$.

114. Subcomm. on Retirement Income and Employment of the Select House Comm. on Acing, 95th Cong., 2d Sess., Women in Midlife-Security and Fulfillment (Part 1) 86 (Comm. Print 1978).

115. Id. at 90 .

116. See supra text accompanying notes $76-82$. 
doctrine since, as noted above, the general nature of the discrimination can be said to parallel the situation described in Griggs. ${ }^{117}$ Even if courts are not inclined to accept that analogy and apply the doctrine, the displaced homemaker should be able to recover under the disparate treatment doctrine with thorough documentation of her experience and skills.

\section{B. Disparate Treatment and the Displaced Homemaker}

Use of the McDonnell Douglas disparate treatment doctrine in an ADEA action brought by a displaced homemaker requires that she claim that she is a member of the protected class, that she applied for the job and was rejected, and that after the rejection, the employer continued to seek applicants for the job. ${ }^{118}$ She could also establish a prima facie case using statistical information, direct evidence of discrimination, or circumstantial evidence other than that used in the McDonnell Douglas test. ${ }^{119}$ Although the burden of proof remains with the plaintiff once she establishes a prima facie case, the burden shifts to the employer to produce a legitimate nondiscriminatory reason for the decision not to hire. ${ }^{120}$

For the displaced homemaker, the stumbling block is the same as with the disparate impact doctrine. She might claim to be qualified, based on her own assessment of her experience in uncompensated jobs, although the employer will most likely cite lack of experience as the nondiscriminatory reason for the decision. Even if the employer's claim is lack of any experience rather than the lack of documented experience, in the absence of credible evidence that plaintiff's uncompensated experience is valuable in the context of the job sought, there is some likelihood that the employer's defense will prevail.

\section{Establishing the Qualifications of the Displaced Homemaker}

Section 3(a) of the ADEA, captioned Education and Research Program, directed the Secretary of Labor to "undertake studies and provide information to labor unions, management, and the general public concerning the needs and abilities of older workers, and their potentials for continued employment and contribution to the economy," and suggested at least four means of accomplishing this directive. ${ }^{121}$

117. Id.

118. McDonnell Douglas Co. v. Green, 411 U.S. 792, 800 (1973).

119. Blackwell v. Sun Elec. Corp., 696 F.2d 1176, 1180 (6th Cir. 1983).

120. Texas Dep't of Community Affairs v. Burdine, 450 U.S. 248 (1981).

121. 29 U.S.C. \& 622(a) (1982). The four means are listed as follows:

(1) undertake research, and promote research, with a view to reducing barriers to the employment of older persons, and the promotion of measures for utilizing their skills;

(2) publish and otherwise make available to employers, professional societies, the various media of communication, and other interested persons the findings of studies and other materials for the promotion of employment;

(3) foster through the public employment service system and through cooperative effort the development of facilities of public and private agencies for expanding the opportunities and potentials of older persons; and

(4) sponsor and assist State and community informational and educational programs. 
It is not clear that any information produced as a result of the ADEA's directive has addressed misconceptions about the abilities of the displaced homemaker. Although the abilities of a displaced homemaker job applicant will vary with the applicant, as do the abilities of any person applying for a job, information is available that could serve as the basis for evaluation of the skills used in homemaking tasks. ${ }^{122}$ In addition, displaced homemakers would be encouraged to set forth their credentials in a manner capable of assessment if there was some indication that potential employers would seriously consider them. Widespread dissemination of research and information by the Department of Labor or by other private and public entities could alert potential employers to methods for evaluating such experience. Such a technique might provide courts and plaintiffs with information providing a basis for judicial notice for establishment of a prima facie case of disparate treatment that could not easily be rebutted by a claim of lack of experience.

Recent efforts to obtain equitable distribution of a couple's assets upon their divorce could be helpful in evaluating work traditionally done by displaced homemakers. Just as employers consider a veteran's time in military service when determining years of job experience, an employer could, if presented with sufficient evidence, determine even more accurately the equivalent value of a homemaker's experience.

One case recognizing the "equitable distribution" theory relied heavily on the expert testimony of an employment specialist who established requirements of each job category that the divorcing wife had assumed during her marriage, the preliminary hourly wage for each job listed, and the total weekly salary for her work. ${ }^{123}$ The value established for the homemaking services was $\$ 41,277.08 .^{124}$ The expert then evaluated the services performed by an executive housekeeper and equated those to a junior level management position. ${ }^{125}$ Using wage scales reported by the United States Wage and Salary Administration, he was able to figure compensation for those functions as well as the value of Social Security contributions for that position.126 After testimony about the role of the executive wife and the fitness of the wife in question for that position, he was asked about her employability at age fiftynine with only a high school education and documented work experience as a secretary more than thirty years before. ${ }^{127}$

122. See generally M. Minton \& J. Block, What Is a Wife Worth? (1983).

123. Gallagher v. Gallagher (Ill. Cook County Cir. Ct.) (unreported case discussed in M. Minton \& J. BLock, supra note 122, at 53-80), aff'd, 60 Ill. App. 3d. 26, 376 N.E. 2d 279 (1978).

124. Id. at 76.

Undoubtedly economists would argue that this number is inflated since if homemaking were a compensated activity the labor force wishing to participate in the activity would increase, thereby decreasing the cost of the labor. By the same token, however, sociologists might argue that the worth assessed is not accurate in that women seem to assume some of these duties regardless of the cost-benefit ratio involved. Whether the figures arrived at can be said to be the true economic or sociological value of the work, they are figures that have some basis in fact and can constitute a point from which evaluations can be made.

125. Gallagher, reviewed by M. Minton \& J. BLock, supra note 123, at 76.

126. Id.

127. Id. 
My opinion is that she is unemployable at the present and in the future because of the standard hiring practice in the labor market. The individual has no ascertainable skills, no work history, no letters of recommendation. The company's group benefits such as medical and life insurance would be expensive to extend to such an individual. Even if she had a fair amount of clerical skills, the job market would be limited and almost nonexistent. Employer profitability would be minimal in that this individual is at the bottom of the pyramid when rating each category of qualifications. ${ }^{128}$

Although the equitable distribution cases are only concerned with the division of assets on divorce or separation, they provide a basis for classifying the jobs of a homemaker and therefore for evaluation of a particular job applicant's work experience. Because employers often do not delve into the quality of the job experience for any applicant, but rather simply verify employment or military service, a simple listing could provide the basis for equitable evaluation of the professional experience of displaced homemakers. Where specific recommendations are required, they should be available for volunteer activities outside the home, and may even be obtainable from outside observers for jobs associated with housekeeping and child care.

This discussion assumes that employers will be willing to take into account or courts will mandate the recognition of the factors set forth above. Some states have done so by equitable distribution statutes. ${ }^{129}$ Others have been less willing. In one recent case in which a displaced homemaker sought unemployment benefits because of her inability to find work after a divorce from her university faculty husband, the Idaho Supreme Court rejected her claim that she had performed what were in essence employment services for him and for the university, in part because of her lack of a written employment contract with either. ${ }^{130}$

\section{VI}

\section{ConCLUSION}

Although the federal appellate courts that have considered the question have agreed that claims under the Age Discrimination in Employment Act require only proof of disparate impact, Justice Rehnquist, the only Supreme Court Justice to speak to the issue, has maintained that ADEA claims require more. Some lower federal courts and some legal writers have agreed with Justice Rehnquist's position.

Congressional attention to the plight of displaced homemakers has shown that the homemakers are less able than other persons similarly situated to compete for first-time employment outside the home and that the difficulty is directly and indirectly attributable to their age and gender. Despite the recognition that a homemaker's services are essential for the orderly functioning of society, an argument can be made that the age and gender distinctions are based on personal choices made by these women to forgo

\section{Id.}

129. E.g., Ill. Rev. Stat. ch. 40, §503(c)(1) (1981); N.Y. Dom. Rel. LaW \& 236(B)(5),(7) (MCKINNEY 1984).

130. Curtis v. Idaho Dep't of Employment, 107 Idaho 956, 695 P.2d 341 (1985). 
employment outside the home in favor of uncompensated work. There is also an argument, however, that these women have developed measurable skills that are not taken into account or are discounted when they apply for paid employment.

It is much easier to prove the discriminatory impact of this discounting on older women than it would be to prove discriminatory treatment. Under the disparate treatment doctrine, a displaced homemaker would have to combat the argument that her lack of paid employment experience was a legitimate non-discriminatory reason for an employer's refusal to hire her. The development of means by which an employer could assess skills gained through volunteer work or other unpaid work outside the home could help defeat such an argument.

A recent federal district court case involving a woman who had been employed, but dropped out of the full-time labor force for a period, found that use of a "recency" factor to rate that employee's application for employment had a discriminatory impact on older women, and that such discrimination was based on both age and gender. ${ }^{131}$ The rationale the court adopted in that case is applicable to displaced homemakers.

Education of employers and potential employees of the value of work that traditionally has been accorded no value, and some means to assess that value, could help employers and displaced homemakers avoid the necessity of bringing ADEA or Title VII suits to test this theory, or alternatively could serve as the basis for proof in actions that might be brought. Section 3(a) of the ADEA directed the Secretary of Labor to undertake studies and provide information to labor unions, management, and the general public about the needs and abilities of older workers. Wider distribution of available information about displaced homemakers and the work of homemakers generally, even without new studies, could provide the education necessary.

131. See supra notes 105-09 and accompanying text. 